\title{
Foliar Application of Salicylic Acid Stimulates Flowering and Induce Defense Related Proteins in Finger Millet Plants
}

\author{
Manikandan Appu, Sathiyabama Muthukrishnan* \\ Department of Plant Science, Bharathidasan University, Tiruchirappalli-620024, TamilNadu, India \\ *Corresponding Author: sathiyabamam@yahoo.com
}

Copyright (C) 2014 Horizon Research Publishing All rights reserved.

\begin{abstract}
Induction of defense related proteins, such as chitinase, protease inhibitor, peroxidase, polyphenol oxidase was studied in finger millet plants treated with salicylic acid. Treated plants showed changes in the isoform pattern with new isoformsof chitinase,protease inhibitor, peroxidase, and polyphenol oxidase. Salicylic acid (SA) treatment stimulates flowering and grain set. Induction of defense related proteins in salicylic acid treated finger millet plants may play a role in disease resistance.
\end{abstract}

Keywords Finger Millet, Salicylic Acid, Chitinase, Protease Inhibitor, Peroxidase, Polyphenol Oxidase

\section{Introduction}

Finger millet (Eleusine coracana L.) is an important cereal in East Africa and India [1]. Nutritionally, finger millet is equal or superior to other staple cereals, especially in minerals [2]. Finger millet is susceptible to more than twenty pathogens [3] and results in yield loss.

SA treatment is known to activate plant systemic resistance commonly associated with activation of defense genes $[4,5,6,7]$. We have reported earlier that SA treatment to groundnut leaves induced defense proteins in intercellular washing fluid [8] and promotes resistance towards Puccinia arachidis. Hence, an attempt has been made to induce antifungal hydrolases such as chitinase, protease inhibitor, peroxidase, polyphenol oxidase in finger millet plants by spraying with SA.

The primary objective of this study was to characterize the effects of SA spray on induction of defense proteins such as chitinase, protease inhibitor, peroxidase, polyphenol oxidase in finger millet plants.

\section{Materials and Methods}

\subsection{Plant Material}

Seeds of susceptible (IE 2572) cultivar of ragi were obtained from ICRISAT, and hrapradesh, India.

\subsection{Salicylic Acid Preparation}

Different concentrations of SA $(0.1 \mathrm{mM}, 0.5 \mathrm{mM}, 0.75 \mathrm{~mm})$ were prepared as described earlier [8].

\subsection{InVitro Seed Germination Test}

Seeds were imbibed $(50$ seeds/ $5 \mathrm{ml})$ in different concentration of SA $(0.1 \mathrm{mM}, 0.5 \mathrm{mM}, 0.75 \mathrm{~mm})$ and kept in a rocker overnight. Seeds immersed in water served as control. The seeds were then kept on a petri plate and allowed to germinate under moist condition. The percentage of germination was measured at $12,24 \mathrm{~h}$.

\subsection{Application of Salicylic Acid to Finger Millet Plants}

Finger millet seeds were washed thoroughly in distilled water and placed in an earthen pot (5seeds/pot) containing soil and manure. They were grown under glass house condition. To 35day old finger millet plants $0.1 \mathrm{mM}$ of SA was applied as a foliar spray. Water sprayed plants served as control.

For each experiment, 20 plants were used in replicates and the experiments were repeated twice. Leaves from treated and control plants were removed after 10, 20 days and used for protein extraction.

\subsection{Protein Extraction and Estimation}

Proteins were extracted using $0.01 \mathrm{M}$ Tris- $\mathrm{HCl}$ buffer, $\mathrm{pH}$ $6.8(1 \mathrm{~g} / 2 \mathrm{ml})$. They were centrifuged at $10,000 \mathrm{G}$ for 10 minutes and soluble fraction was used for estimation of protein and further enzyme localization. Protein present in the soluble fraction was estimated by Bradford's method [9]. 


\subsection{SDS-PAGE Analysis of Chitinaseand Protease Inhibitor}

Proteins $(40 \mu \mathrm{g})$ were separated on $10 \%$ SDS-PAGE according to the method of Laemmli [10] along with standard molecular mass proteins (Genei co., Bangalore).

For chitinase localization, $0.1 \%(\mathrm{w} / \mathrm{v})$ glycol chitin were included in the separation gel. After electrophoresis, the gel was stained with Calcoflour White M2R according to the procedure of Trudel and Asselin [11].

For Protease inhibitor localization, the gels were incubated with Casein $(1 \%, w / v)$ at $37^{\circ} \mathrm{C}$ for 90 minutes and stained with $0.1 \%$ (w/v) Coomassie Birlliant Blue R 250 as described by Garcia-Carrero et al., [12].

\subsection{Activity Gel Electrophoresis for Peroxidase \& Polyphenol Oxidase}

To study the expression pattern of different isoforms of peroxidases due to treatment, activity gel electrophoresis was carried out. For native anionic polyacrylamide gel electrophoresis Davis [13], resolving gel of $10 \%$ acrylamide concentration and stacking gel of $4 \%$ acrylamide concentration was prepared.

Protein samples $(40 \mu \mathrm{g})$ were separated along with Native protein markers (Genei Co., Bangalore). For peroxidase visualization, after electrophoresis the gel was washed with $25 \mathrm{ml}$ of $0.05 \mathrm{M}$ Citrate phosphate buffer ( $\mathrm{pH} 5.4$ ) twice, followed by incubation with $3 \%(\mathrm{v} / \mathrm{v})$ hydrogen peroxide along with guaiacol.

For PPO visualization, the gel was incubated with $0.1 \%$ $(\mathrm{w} / \mathrm{v}) \mathrm{p}$-phenylene diamine in $0.1 \mathrm{M}$ potassium phosphate buffer $\mathrm{pH} 7.0$ for 20 minutes followed by the addition of 10 $\mathrm{mM}$ Catechol in the same buffer with gentle shaking, till the appearance of dark brown bands [14]. The gel was washed with distilled water and photographed.

\subsection{Effect of Salicylic Acid on Flowering}

Control and treated plants were monitored for initiation of flowering, number of flowers etc., at different age level.

\subsection{Statistical Analysis}

All the data were subjected to one-way analysis of variance to determine the significance of individual difference in $p<0.01$ and 0.05 levels. All statistical analysis was conducted using SPSS 16 software support.

\section{Results}

In vitro seed germination test, showed that treatment of SA to finger millet seeds induced germination (Figure.1). Induction of defense proteins by SA treatment was studied in ragi. The enzymes viz., chitinase, protease inhibitor, peroxidase, polyphenol oxidase were induced in SA treated plants.

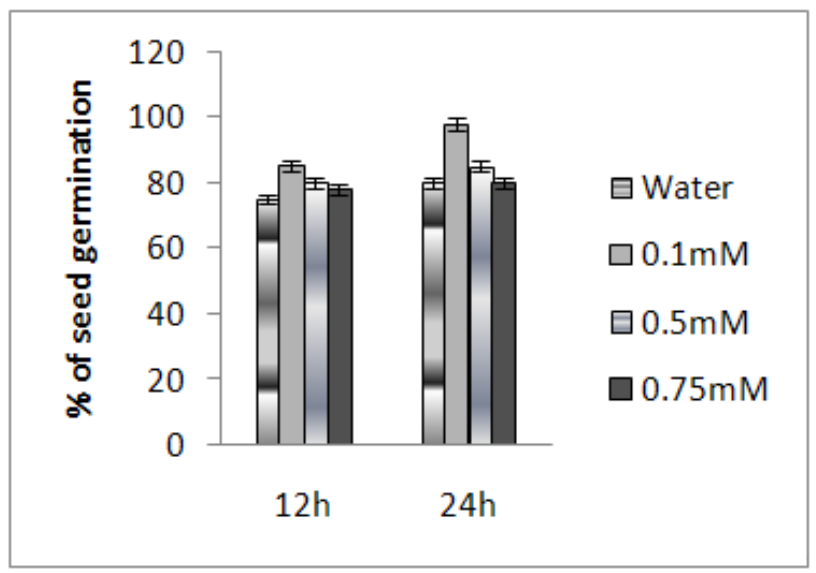

Figure 1. Percentage of seed germination in control and SA treated finger millet seeds

Two isoforms of chitinase with a molecular mass $(52,77$ $\mathrm{kDa}$ ) were constitutively expressed with low activities in the healthy tissues of finger millet plants. Their activities were remarkably induced in the extract of treated leaves at 10,20 days after treatment with SA. A new chitinase isoform of molecular mass $50 \mathrm{kDa}$ was observed 10day after treatment in leaves of SA treated plants. Apart from these isoforms, three more isoforms $(6.6,19,42 \mathrm{kDa})$ were observed in leaves of SA treated plants on 20day after treatment (Figure 2).

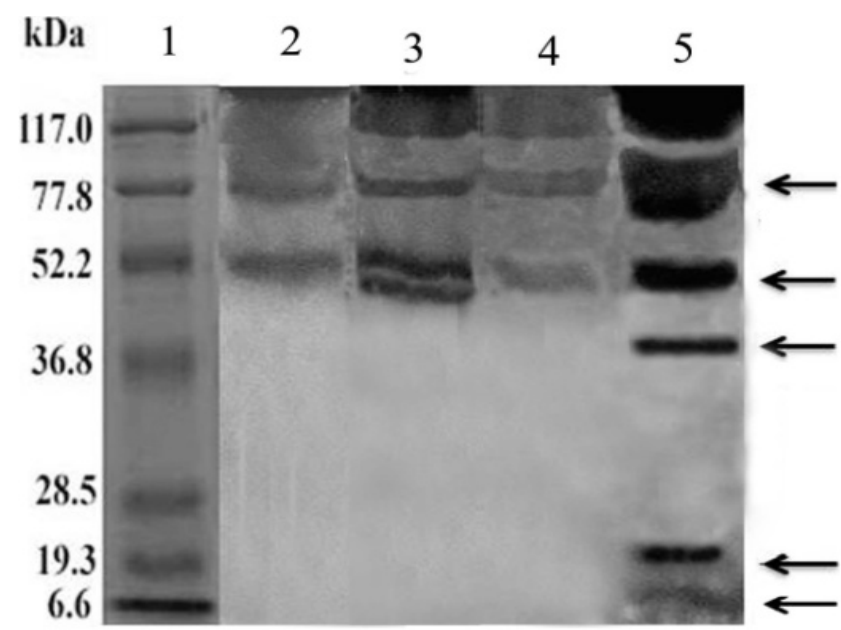

Lanes: 1-Marker; 2-Leaf Extract of Control plants(Water) after 10 day; 3-Leaf Extract of treated plants 10day after treatment; 4-Leaf Extract of (Water) control plants after 20 day; 5-Leaf Extract of Salicylic acid treated plants 20 days after treatment.

Figure 2. SDS-PAGE showing chitinase isoforms in leaves of control and salicylic acid treated finger millet plants

Two new isoforms of molecular mass $(28.5,36.8 \mathrm{kDa})$ with protease inhibitor activity was observed in SA treated plants on 10, 20 day after treatment, apart from the constitutive isoforms $(75,50 \mathrm{kDa})$ (Figure 3).

Protein separated on native PAGE showed new isoforms of peroxidase in plants treated SA, 20 days after treatment. The constitutive enzyme remains unaltered in control plant 
(Figure 4).

Gels stained for polyphenol oxidase also showed new isoform in treating plants (Figure 5).

Finger millet plants treated with SA results in early flowering, on 50day itself. In control plants flowering starts after 60 days. Also treated plants stimulated more number of flowers and fruit set when compared to control (Table 1, Figure 6).

Table 1. Effect of salicylic acid on flowering.

\begin{tabular}{|c|c|c|}
\hline Treatment & $\begin{array}{c}\text { No. of flowers/plant } \\
\text { (50 day) }\end{array}$ & $\begin{array}{c}\text { No. of flowers/plant } \\
\text { (60 day) }\end{array}$ \\
\hline Control & 0 & 03 \\
Salicylic acid & 04 & 08 \\
\hline
\end{tabular}

\begin{tabular}{|c|c|c|c|c|c|}
\hline kDa & 1 & 2 & 3 & 4 & 5 \\
\hline 7.0 & $\longrightarrow$ & & & & \\
\hline 77.8 & $\longrightarrow$ & $=$ & $=$ & $=$ & 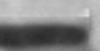 \\
\hline 52.2 & $\rightarrow$ & & & & 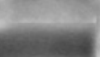 \\
\hline 36.8 & 84 & & & & cass \\
\hline 28.5 & $5=$ & & & & \\
\hline $\begin{array}{r}19.3 \\
6.6\end{array}$ & $6=$ & & & & \\
\hline
\end{tabular}

Lanes: 1-Marker; 2-Leaf Extract of Control plants(Water) after 10 day; 3Leaf Extract of treated plants 10day after treatment; 4- Leaf Extract of (Water) control plants after 20 day; 5- Leaf Extract of Salicylic acid treated plants 20 days after treatment.

Figure 3. SDS-PAGE showing Protease Inhibitor isoforms in leaves of control and salicylic acid treated finger millet plants

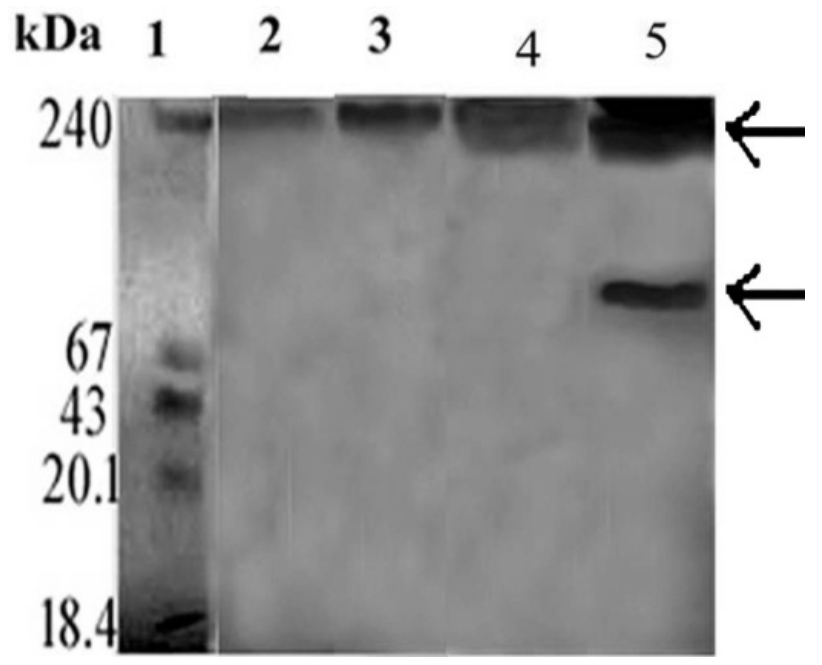

Lanes: 1-Marker; 2-Leaf Extract of Control plants(Water) after 10 day; 3-Leaf Extract of treated plants 10day after treatment; 4-Leaf Extract of (Water) control plants after 20 day; 5-Leaf Extract of Salicylic acid treated plants 20 days after treatment.

Figure 4. Native-PAGEshowing Peroxidase isoforms in leaves of control and salicylic acid treated finger millet plants

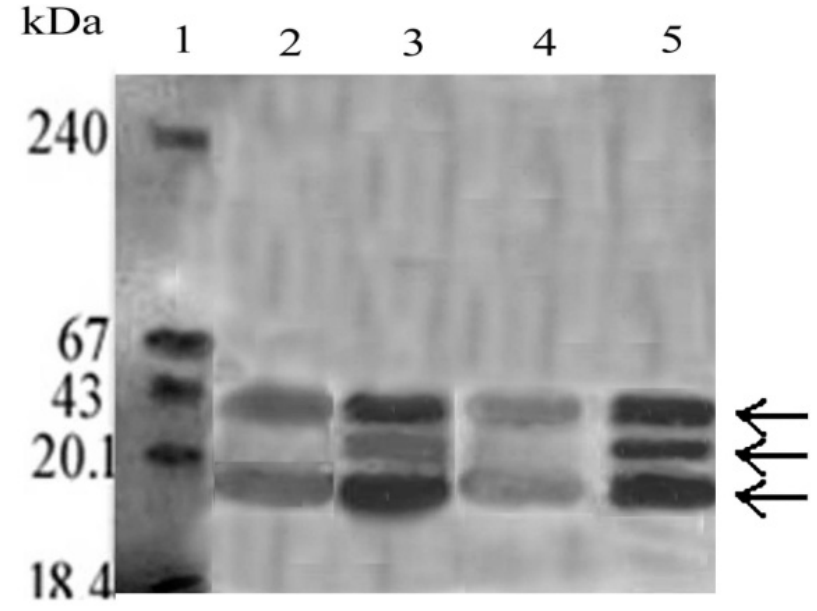

Lanes: 1-Marker; 2-Leaf Extract of Control plants(Water) after 10 day; 3-Leaf Extract of treated plants 10day after treatment; 4-Leaf Extract of (Water) control plants after 20 day; 5-Leaf Extract of Salicylic acid treated plants 20 days after treatment.

Figure 5. Native-PAGE showing Polyphenoloxidase isoforms in leaves of control and salicylic acid treated finger millet plants
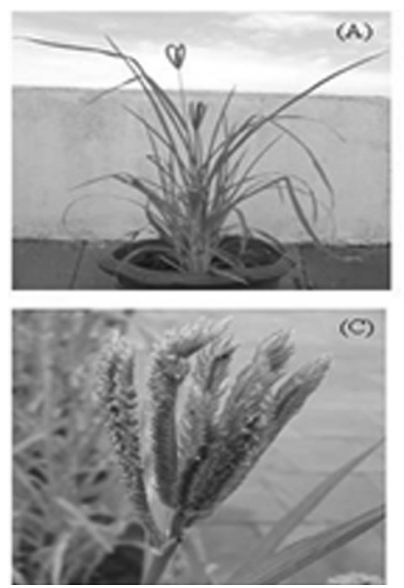

A-60 day old control plant with flowers; B- 50 day old treated plant with flowers; C- 60 day old control plant with flowers; D-60 day old treated plant with flowers and grain set.

Figure 6. Flowering in control and salicylic acid treated finger millet plants.

\section{Discussion}

Plants have defense genes that need appropriate stimuli or signals to be activated. Inducing the plant's own defense mechanisms by application of an inducer is a novel technique for plant protection.

Our results demonstrated that foliar application of $0.1 \mathrm{mM}$ SA strongly induced the synthesis and accumulation of chitinase, protease inhibitor, peroxidase, polyphenol oxidase in the tissues of finger millet. This may be attributed to the availability of specific receptors for the inducers in finger millet plants.

Synthesis and accumulation of chitinase have been reported to play an important role in plant defense $[15,16]$. In plants, the presence of protease inhibitors is mainly considered as storage proteins and as defense tools [17]. 
Since leaves are the major tissues attacked by pest and pathogens, the accumulation of protease inhibitor was maximum in leaves [18]. In our study, chitinase and protease inhibitor has been induced by SA application. The present study records that higher accumulation of enzymes involved in defense metabolism in Ragi leaf tissues treated with SA.

Peroxidases are known one of the important parts of the enzymatic defense of plant cells under stress conditions $[19,20]$.

Peroxidase is a key enzyme in the biosynthesis of lignin [21]. Increased activity of peroxidases has been elicited by PGPR in different plants such as cucumber [22] tomato [23]ragi [24]. In our study, increased peroxidase activity has been recorded in SA treated plants. Similarly polyphenol oxidase activity was induced by SA treatment in finger millet plants. Disease resistance is often correlated with an enhanced activity to produce polyphenol around the site of infection. Chen et al., [22] reported that polyphenol oxidase activity was induced in cucumber root tissues by Pythium aphanidermatum infection.

The defense gene products include peroxidase, polyphenol oxidase that catalyze the formation of lignin and phenylalanine ammonia lyase that is involved in phytoalexin and phenolics biosynthesis. Induction of defense enzyme makes the plant resistant to pathogen invasion [25].

$\mathrm{SA}$ is a phenolic plant growth regulator having a role in regeneration of physiological processes in plants [26]. The role of SA in seed germination [27] enzyme activity [28] plant growth and yield [29] have been reported.

Apart from the induction of defense enzymes, SA also promotes early flowering and induce more flowering in finger millet plants. SA treatment stimulates flowering in Lemna plants [30] Taken together with all these data SA can be used as a best inducer for induction of defense proteins, flowering in finger millet plants.

\section{REFERENCES}

[1] O'Kennedy, M.M. Grootboom, A. and Shewry, P.R. 2006. Harnessing sorghum and millet biotechnology for food and health. J. Cereal Sci. 44: 224-235.

[2] Latha, M.A. VenkateswaraRao, K. and Dashavantha-Reddy, V. 2005. Production of transgenic plants resistant to leaf blast disease in finger millet (Eleusine coracana (L.) Gaertn.). Plant Sci. 169: 657-667.

[3] Radjacommare, R. Ramanathan, A. Kandan, A. Harish, S. Thambidurai, G. Sible, G.V. Ragupathi, N. and Samiyappan, R. 2004. PGPR mediates induction of pathogenesis-related (PR) protein against the infection of blast pathogen in resistant and susceptible ragi [Eleusine coracana (L.) Gaertner] cultivars. Plant and soil. 266: 165-176.

[4] Fought, L. and Ku'c, J. 1996. Lack of specificity in plant extracts and chemicals as inducers of systemic resistance in cucumber plants to anthracnose. J. Phytopathol. 144: 1-6.

[5] Van Loon, L.C. 1997. Induced resistance inplants and the role of pathogenesis-related proteins. Eur. J. Plant Pathol. 103: 753-65.

[6] Gunes, A. Inal, A. Alpaslan, M. Eraslan, F. Bagci, E.G. and Cicek, N. 2007. Salicylic acid induced changes on some physiological parameters symptomatic for oxidative stress and mineral nutrition in maize (Zea mays L.) grown under salinity. J. Plant Physiol. 164 (6): 728-736.

[7] Catinot, J. Buchala, A. Mansour, E.A. Metraux, J.P. 2008. Salicylic acid production in response to biotic and abiotic stress depends on isochorismate in Nicotiana benthamiana. FEBS Lett. 582: 7473- 478.

[8] Sathiyabama, M. Balasubramanian, R. 1999. Treatment of groundnut leaves with salicylic acid control the development of rust disease caused by Puccinia arachidis speg. J. Plant Dis. Prot. 106: 166-173.

[9] Bradford, M.M. 1976. A Rapid and Sensitive Method for the Quantitation of Microgram Quantities of Protein Utilizing the Principle of Protein-Dye Binding. Analytical Biochem. 72: $248-254$.

[10] Laemmli, U.K. 1970. Cleavage of Structural Proteins during the Assembly of the Head of Bacteriophage T4. Nature. 227: 680-685.

[11] Trudel, J. Asselin, A. 1989. Detection of chitinase activity after polyacrylamide gel electrophoresis. Anal. Biochem. 178 (2): 362-366.

[12] Garcia-Carreno, F.L. Dimes, L.E. and Haard, N.F. 1993. Substrate gel electrophoresis for composition and molecular weight of proteinases and proteinaceous proteinase inhibitors. Anal. Biochem. 214: 65-69.

[13] Davis, B. J. 1964. Disc electrophoresis. Method and application to human serum protein. Ann. N. Y. Acad. Sci. 121: 404-427.

[14] Jayaraman, K.S. Ramanuja, M.N. Vijayarahavan, P.K. and Vaidyanathan, C.S. 1987. Oxidative enzyme in pearl millet. Food Chem. 24: 203.

[15] Maurhofer, M.Hase, C. Meuwly, P. Metraux, J.P. and Defago, G. 1994. Induction of systemic resistance of tobacco to Tobacco Necrosis Virus by the root-colonizing Pseudomonas fluorescens strain CHA0 - influence of the gacA gene and of pyoverdine production. Phytopathology. 84 (2): 139-146.

[16] Van Loon, L.C. 1990. The nomenclature of pathogenesis-related proteins. Physiol. Mol. Plant Pathol. 37: 229-230.

[17] Azzouz, H. Cherqui, A. Campan, E.D.M. Rahbe, Y. Duport, G. Jouanin, L. et al. 2005. Effects ofplant protease inhibitors, Oryzacystatin I and soybean Bowman-Birkinhibitor,on the aphid Macrosiphum euphorbiae (Homoptera, Aphididae) and its parasitoid Aphelinus abdominalis (Hymenoptera, Aphelinidae). J. Insect Physiol. 51: 75-86.

[18] Bijinaa, B. Sreeja Chellappana, Soorej M. Basheera, Elyasa, K.K. Ali H. Bahkalic, Chandrasekarana, M. 2011. Protease inhibitor from Moringaoleifera leaves: Isolation, purification, and characterization. Process Biochemistry. 46: 2291-2300.

[19] Gaspar, T. Penel, C. Thorpe, T. and Greppin, H. 1982. Peroxidases: A survey of their biochemical and physiological roles in higher plants. Univ. of Geneva, Switzerland. 
[20] Hammerschmidt, R. Nuckles, E. M. and Kuc, J. 1982. Association of enhanced peroxidase activity with induced systemic resistance of cucumber to Colletotrichum lagenarium. Physiological Plant Pathology. 20: 73-82.

[21] Bruce, R.J. and West, C.A. 1989. Elicitation of lignin biosynthesis and isoperoxidase activity by pectic fragments in suspension cultures of castor bean. Plant Physiol. 91: 889-897.

[22] Chen, J.F. and Kirkbride, J.H. 2000, A new synthetic species Cucumis (Cucurbitaceae) from interspecific hybridization and chromosome doubling. Brittonia. 52: 315-319.

[23] Ramamoorthy, V. Raguchander, T. and Samiyappan, R. 2001a. Induction of defense-related proteins in tomato roots treated with Pseudomonas fluorescens Pfl and Fusarium oxysporum f. sp. lycopersici. Plant and Soil. (in press).

[24] Radjacommare, R. Ramanathan, A. Kandan, A. Sible, G.V. Harish, S. and Samiyappan, R. 2004. Purification and anti-fungal activity of chitinase against Pyricularia grisea in finger millet. World Journal of Microbiology \& Biochemistry. 20: 251-256.
[25] Van Loon, L.C. Bakker, P. A. H. M. and Pieterse, C. M. J. 1998. Systemic resistance induced by rhizosphere bacteria. Annu. Rev. Phytopathol. 36: 453-83.

[26] Sakhabutdinova, R. Fatkhutdinova, D.R. Bezrukova, M.V. and Shakirova, F.M. 2003. Salicylic acid prevents the damaging action of stress factors on wheat plants. Bulg. J. Plant Physiol. special issue: 314-319.

[27] Cutt, J.R. and Klessing, D.F. 1992. Salicylic acid in plants: A changing perspective. Pharmaceu. Technol. 16:25-34.

[28] Dolatabadian, A. Sanavy, S.A.M.M. and Chashmi, N.A. 2008. The effects of foliar application of ascorbic acid (Vitamin C) on antioxidant enzyme activities, lipid peroxidation and proline accumulation of canola (Brassica napus L.) under conditions of salt stress. J. Agron. Crop Sci.194: 206-213.

[29] Hussein, M.M. Balbaa, L.K. and Gaballah, M.S. 2007. Salicylic acid and salinity effects on growth of maize plants. Res. J. Agric. Biol. Sci. 3: 321-328.

[30] Raskin, I. 1992. Role of Salicylic acid in plants. Ann. Rev. Plant Physiol. Plant Mol. Biol. 43: 439-463. 